\title{
Article/Artigo
}

\section{Malacological survey of Biomphalaria snails in municipalities along the Estrada Real in the southeast of the State of Minas Gerais, Brazil}

\author{
Pesquisa malacológica de Biomphalaria em municípios da Estrada Real, situados no sudeste \\ do Estado de Minas Gerais
} Sandra Helena Cerrato Tibiriçá ${ }^{1}$, Adalberto Mitterofhe ${ }^{2}$, Milton Ferreira de Castro ${ }^{2}$, Adilson da Costa Lima ${ }^{2}$,
Murilo Gonçalves ${ }^{2}$, Izabella de Oliveira Pinheiro ${ }^{2}$, Corina da Costa Freitas ${ }^{3}$, Ricardo José Paula de Souza e
Guimarães $^{4}$, Omar dos Santos Carvalho ${ }^{4}$ and Elaine Soares Coimbra

\begin{abstract}
Introduction: The increasing practice of ecotourism and rural tourism in the State of Minas Gerais, Brazil, highlights the importance of studies concerning the occurrence of potential intermediate hosts of Schistosoma mansoni. This study aimed to identify species of Biomphalaria snails in municipalities along the Estrada Real, an important Brazilian tourism project. Methods: The specimens were collected in different water collections of 36 municipalities along the Estrada Real in the southeast of the State of Minas Gerais. Biomphalaria species were characterized using both morphological and molecular approaches. The research was conducted between August 2005 and September 2009 and all the sites visited were georeferenced using GPS. Results: Six Biomphalaria species were found in 30 of the 36 municipalities studied: glabrata, tenagophila, straminea, peregrina, occidentalis and schrammi. The first three species of Biomphalaria, recognized as intermediate hosts of S. mansoni, were present in $33.3 \%, 47.2 \%$ and $8.3 \%$ of the municipalities studied, respectively. The mollusks were found in different types of water collections and no infection by S. mansoni was detected. The highest occurrence of Biomphalaria concentration was verified in the area covered by the Caminho Novo route (Diamantina/MG to Rio de Janeiro/RJ) Conclusions: Considering the occurrence of schistosomiasis in the State of Minas Gerais and the socioeconomic repercussions involved in the Estrada Real Project, this work focuses on the vulnerability of water collections due to the presence of Biomphalaria mollusks and emphasizes the need for epidemiological surveillance and sanitary and educational measures integrated with the local community and tourism sectors.
\end{abstract}

Keywords: Biomphalaria. Schistosomiasis. Estrada Real. Tourism. Ecotourism. Spatial distribution.

\section{RESUMO}

Introdução: $\mathrm{O}$ aumento das práticas de ecoturismo e turismo rural, em Minas Gerais, Brasil, evidencia a importância de se realizarem estudos sobre a ocorrência de hospedeiros intermediários do Schistosoma mansoni, no estado. O presente trabalho objetivou a busca e identificação das espécies de caramujos Biomphalaria encontrados em municípios mineiros pertencentes à Estrada Real, um importante projeto de turismo brasileiro. Métodos: Os moluscos foram coletados em 36 municípios da Estrada Real, no sudeste de Minas Gerais. A pesquisa foi realizada de agosto de 2005 a setembro de 2009 e todos os locais visitados foram georreferenciados com o uso de GPS. Resultados: Dos 36 municípios estudados, 30 apresentaram a ocorrência de pelo menos uma entre as seis espécies de Biomphalaria: glabrata, tenagophila, straminea, peregrina, occidentalis e schrammi. As três primeiras espécies citadas, reconhecidas como hospedeiras intermediárias do S. mansoni, estavam presentes em 33,3\%, $47,2 \%$ e $8,3 \%$ dos municípios estudados, respectivamente. Os moluscos foram encontrados em diferentes tipos de coleções hídricas e em nenhum deles foi detectada infecção pelo $S$. mansoni. Houve maior ocorrência de Biomphalaria na área referente ao Caminho Novo (Diamantina/ MG ao Rio de Janeiro/RJ). Conclusões: Considerando-se a ocorrência da esquistossomose, no Estado de Minas Gerais, e as repercussões socioeconômicas que envolvem o projeto Estrada Real, este trabalho aponta para a vulnerabilidade das coleções hídricas devido à presença de moluscos Biomphalaria e enfatiza a necessidade de vigilância epidemiológica e medidas educativas e sanitárias integradas com a comunidade local e setores de turismo.

Palavras-chaves: Biomphalaria. Esquistossomose. Estrada Real. Turismo. Ecoturismo. Distribuição espacial.

1. Departamento de Morfologia, Instituto de Ciências Biológicas, Universidade Federal de Juiz de Fora, Juiz de Fora, MG. 2. Coordenadoria de Epidemiologia e Vigilância em Saúde, Gerência Regional de Saúde de Juiz de Fora, Secretaria Estadual de Saúde de Minas Gerais Juiz de Fora, MG. 3. Divisão de Processamento de Imagens, Instituto Nacional de Pesquisas Espaciais, São José dos Campos, SP. 4. Laboratório de Helmintologia e Malacologia Médica, Centro de Pesquisas René Rachou, Fundação Oswaldo Cruz, Belo Horizonte, MG. 5. Departamento de Parasitologia, Microbiologia e Imunologia, Instituto de Ciências Biológicas, Universidade Federal de Juiz de Fora, Juiz de Fora, MG.

Address to: Dra. Elaine Soares Coimbra. Depto Parasitol Microbiol Imunol/ICB/UFJF. Campus Universitário, Bairro Martelos, 36036-900 Juiz de Fora, MG, Brasil.

Phone: 5532 2102-3219; Fax: 5532 2102-3214

e-mail: elaine.coimbra@uff.edu.br

Received in 10/09/2010

Accepted in 04/11/2010

\section{INTRODUCTION}

Mollusks of the genus Biomphalaria infected with Schistosoma mansoni maintain the cycle of schistosomiasis in several Brazilian municipalities, despite recent improvements in the socioeconomic status of the population and education programs focusing on health, which were expected to reduce transmission of the disease. The relation between disease occurrence in human populations and the geographical presence of susceptible intermediate hosts is a well documented fact ${ }^{1}$. Poor rural communities continue to be major areas of schistosomiasis transmission ${ }^{1}$. With the phenomena of urbanization (migration to the outskirts of large cities), all aspects of the disease are reappearing, such as: neuroschistosomiasis, pulmonary hypertension, hepatosplenic schistosomiasis, acute episodes, glomerulonephritis and pyogenic liver abscesses ${ }^{1-13}$.

The State of Minas Gerais presents one of the highest prevalence rates for schistosomiasis in Brazil $^{14,15}$. The presence of schistosomiasis in this state causes a number of concerns, not only for the healthcare sector, but also for economic sectors, such as tourism, which involve significant capital.

In the historical context of the economic development of State of Minas Gerais, the term Estrada Real refers to the routes taken by settlers from the time of the discovery of gold in Minas Gerais to the period of its exhaustion ${ }^{16,17}$. The Estrada Real was created by the Portuguese Crown in the $17^{\text {th }}$ century with the intention of controlling the flow of wealth, in the form of gold and diamonds and goods, which passed between the State of Minas Gerais and the coastal city of Rio de Janeiro, the capital of the colony at the that time $\mathrm{e}^{17}$. The association of tourist attractions, including colonial buildings, churches, museums, nature reserves, adventure sports, mineral springs and culinary attractions, led to the creation of the Estrada Real Project. The Estrada Real Project consists of 193 municipalities, 162 of which are in the State of Minas Gerais, nine in the State of Rio de Janeiro and 22 in the State of São Paulo ${ }^{17}$. 
The State of Minas Gerais includes the majority of the municipalities of the Estrada Real Project with great potential for expanding ecotourism and rural tourism, because of the attraction represented by historical-cultural monuments, the diversity of the topography, fauna and flora and water bodies. Thus, mapping the geographical areas vulnerable to the transmission of schistosomiasis becomes a task not only of health surveillance, but also of encouraging productive sectors that drive the economy in this state.

In order to contribute to the generation of georeferenced epidemiological data and the control of schistosomiasis in the municipalities of the Estrada Real Project in southeastern Minas Gerais, this work reports a malacological survey designed to verify the occurrence of mollusks of the genus Biomphalaria and the possibility of infection by S. mansoni.

\section{METHODS}

\section{Study area}

The study municipalities are located in the southeast of the State of Minas Gerais, Brazil, and belong to the Regional Healthcare Administration of Juiz de Fora (Gerência Regional de Saúde, GRS/ $\mathrm{JF}$ ). The state is administratively divided into 13 macroregions. Among these, the southeastern macroregion consists of eight microregions, of which the Juiz de Fora/Lima Duarte/Bom Jardim de Minas microregion is under the responsibility of the GRS/JF. This microregion is composed of 37 municipalities. Of these, 36 were included in the study. The core urban area of the City of Juiz de Fora was not included, because the results of a local malacological survey conducted prior to this study had already been published ${ }^{18}$.

\section{Malacological survey}

Mollusks of the Biomphalaria genus were collected from August 2005 to September 2009, by technicians of the GRS/JF. Catches were made in several areas of the municipalities in order to cover the largest possible area, with the aid of gloves, tongs and dip nets. In all 36 municipalities, the type and quantity of water collection sites surveyed were selected by the following criteria: reported local cases of human schistosomiasis, existence of water bodies (lotic and lentic) whose characteristics favored the occurrence of the Biomphalaria genus and the possibility of contact with human populations. Thus, based in these criteria, at least three water collections in each municipality were surveyed. The points were georeferenced using a Global Positioning System (GPS), Garmin Model II-12, and imported into a Geographic Information System (GIS) to permit visualization of their spatial distribution. Sites in which the presence of Biomphalaria was verified were photographed with a digital camera.

\section{Mollusk identification and examination of Schistosoma} mansoni infection

The captured snails were counted, transported in plastic containers and maintained in the laboratory until identification. Following collection, the snails were transported to the laboratory where they were measured and examined under artificial light. Some specimens from each sample were identified at the Parasitology Laboratory in the Federal University of Juiz de Fora and the Entomology Laboratory of the GRS/JF, Secretaria de Estado de Saúde de Minas Gerais (SES/MG), according to the protocol established by Paraense ${ }^{19,20}$. Some specimens were sent to the
Laboratory of Helminthology and Malacology at the René Rachou Medical Research Center, Oswaldo Cruz Foundation (CPqRR/ FIOCRUZ), for confirmation of species by the technique of polymerase chain reaction $(\mathrm{PCR})^{21}$.

\section{RESULTS}

Research on Biomphalaria was conducted in 36 municipalities, 19 of which form part of the Estrada Real Project, while the remainder are located within the coverage area (Table 1). As presented in Table 1, 30 municipalities were positive for snails of the genus Biomphalaria,

TABLE 1 - Presence of Biomphalaria, the number of catch basins surveyed and snails collected in the municipalities of the Estrada Real in the southeast of the State of Minas Gerais.

\begin{tabular}{|c|c|c|c|}
\hline Municipalities & $\begin{array}{c}\text { Water } \\
\text { collections } \\
\text { studied (n) }\end{array}$ & $\begin{array}{c}\text { Species of } \\
\text { Biomphalaria* }^{*}\end{array}$ & $\begin{array}{c}\text { Snails } \\
\text { collected (n) }\end{array}$ \\
\hline Andrelândia** & 6 & ausent & 0 \\
\hline Aracitaba & 6 & $\mathrm{p}$ & 2 \\
\hline Arantina & 6 & ausent & 0 \\
\hline Belmiro Braga** & 6 & $\mathrm{p}$ & 125 \\
\hline Bias Fortes ${ }^{* *}$ & 6 & $\mathrm{p}$ & 64 \\
\hline Bicas & 5 & $g, t$ & 116 \\
\hline Bocaina de Minas & 4 & ausent & 0 \\
\hline Bom Jardim de Minas & 5 & ausent & 0 \\
\hline Chácara** & 5 & $\mathrm{p}$ & 44 \\
\hline Chiador $^{* *}$ & 8 & $\mathrm{t}, \mathrm{s}$ & 69 \\
\hline Coronel Pacheco** & 17 & $\mathrm{~g}, \mathrm{t}$ & 567 \\
\hline Descoberto & 5 & $\mathrm{~g}, \mathrm{t}$ & 139 \\
\hline Ewbank da Câmara** & 8 & $\mathrm{t}$ & 55 \\
\hline Goianá & 23 & $g, t$ & 1,045 \\
\hline Guarará & 5 & $g, t$ & 20 \\
\hline Liberdade & 6 & $\mathrm{p}$ & 8 \\
\hline Lima Duarte ${ }^{* *}$ & 8 & ausent & 0 \\
\hline Mar de Espanha & 6 & $\mathrm{p}, \mathrm{o}$ & 28 \\
\hline Maripá de Minas & 7 & $g, p$ & 65 \\
\hline Matias Barbosa** & 9 & $\mathrm{t}, \mathrm{sc}$ & 38 \\
\hline Olaria $^{* *}$ & 3 & $\mathrm{p}$ & 9 \\
\hline Oliveira Fortes** & 6 & $t, p$ & 11 \\
\hline Passa Vinte & 6 & $\mathrm{p}$ & 86 \\
\hline Pedro Teixeira** $^{* *}$ & 6 & $\mathrm{p}$ & 35 \\
\hline Pequeri* $^{* *}$ & 12 & $\mathrm{p}$ & 67 \\
\hline Piau $^{* *}$ & 14 & $\mathrm{~g}, \mathrm{t}, \mathrm{s}$ & 394 \\
\hline Rio Novo & 10 & $g, t$ & 135 \\
\hline Rio Preto & 3 & ausent & 0 \\
\hline Rochedo de Minas & 5 & $g, t$ & 160 \\
\hline Santa Bárbara do Monte Verde & 3 & $\mathrm{p}$ & 20 \\
\hline Santa Rita de Jacutinga** & 6 & $\mathrm{p}, \mathrm{t}$ & 16 \\
\hline Santana do Deserto** & 5 & $\mathrm{~g}, \mathrm{t}, \mathrm{s}$ & 195 \\
\hline Santos Dumont** & 6 & $\mathrm{t}$ & 15 \\
\hline São João Nepomuceno & 5 & $g, t, p$ & 38 \\
\hline Senador Cortes & 4 & $\mathrm{p}$ & 11 \\
\hline Simão Pereira** & 8 & $\mathrm{~g}, \mathrm{t}$ & 45 \\
\hline
\end{tabular}

${ }^{*}$ Species of Biomphalaria: t: tenagophila, s: straminea, p: peregrina, o: occidentalis, sc: schrammi. g: glabrata, ${ }^{* *}$ Municipalities that belong to the Estrada Real Project. The other municipalities are part of the coverage area. 
while in six, the presence of these mollusks not observed. Six Biomphalaria species were identified: glabrata, tenagophila, straminea, peregrina, occidentalis and schrammi. B. tenagophila was the most prevalent species and was found in 17 municipalities, followed by B. peregrina, in 16 municipalities and by B. glabrata, in 12. A total of 3,772 specimens of mollusks were collected, all negative for cercariae of S. mansoni (Table 1).

Table 2 shows the water collections visited in the municipalities studied and the number of positive sites for Biomphalaria snails. The sites were classified according to the following definitions intentionally left in their categories as defined in Portuguese to preserve the distinctions between site types: stream, water flowing in a channel; dam, a barrier constructed to contain the flow of water; tank, a large artificial container used to hold water; irrigation ditch, a channel for water irrigation; bog, wet spongy ground containing clay; waterfall, a cascade of water; water tank, a container for supplying water under pressure; water trough, a container providing water for animals; canal, an artificial waterway; spring, water rising from the earth; well, a hole or shaft sunk into the earth to obtain water; and reservoir, a natural or artificial pond or lake used for storage and regulation of water. Among the various water collections, streams were the most positive sites for Biomphalaria species, with 35 locations, followed by dams. The greatest variety of species was found in the dams. Among the 12 water collections surveyed, 10 showed the presence of B. glabrata and/or B. tenagophila (Table 2).
TABLE 2 - Type and quantity of water collection sites in which the occurrence of Biomphalaria was verified.

\begin{tabular}{lcc}
\hline Water collection $^{*}$ & ${\text { Positive sites }(\mathbf{n})^{* *}}^{*}$ & ${\text { Biomphalaria } \text { species*** }^{* *}}^{*}$ \\
\hline Stream & 35 & $\mathrm{~g}, \mathrm{t}, \mathrm{p}, \mathrm{s}$ \\
\hline Dam & 14 & $\mathrm{~g}, \mathrm{t}, \mathrm{s}, \mathrm{p}, \mathrm{o}, \mathrm{sc}$ \\
\hline Tank & 7 & $\mathrm{t}$ \\
\hline Irrigation ditch & 5 & $\mathrm{~g}, \mathrm{t}$ \\
\hline Bog & 2 & $\mathrm{~g}, \mathrm{t}, \mathrm{p}$ \\
\hline Waterfall & 1 & $\mathrm{p}$ \\
\hline Water tank & 1 & $\mathrm{~g}, \mathrm{t}$ \\
\hline Water trough & 1 & $\mathrm{t}$ \\
\hline Canal & 1 & $\mathrm{~s}$ \\
\hline Spring & 1 & $\mathrm{t}, \mathrm{p}$ \\
\hline Well & 1 & $\mathrm{~g}$ \\
\hline Reservoir & 1 & $\mathrm{~g}, \mathrm{p}$ \\
\hline
\end{tabular}

*The sites were classified according to the definitions intentionally left in their categories as defined in Portuguese to preserve the distinctions between site types (explanations in the results). ${ }^{* *}$ Refers to the presence of Biomphalaria, not necessarily infected with Schistosoma mansoni. ${ }^{* *}$ Species of Biomphalaria: g: glabrata, p: peregrina, t: tenagophila, s: straminea, o: occidentalis, sc: schrammi.

Figure 1 shows the coverage area of the Estrada Real Project in Brazil and highlights the positive and negative areas for Biomphalaria snails. A higher concentration of Biomphalaria occurs in the eastern region of the map, in the area covered by the Caminho Novo (Diamantina/MG to Rio de Janeiro/RJ), than in the western region

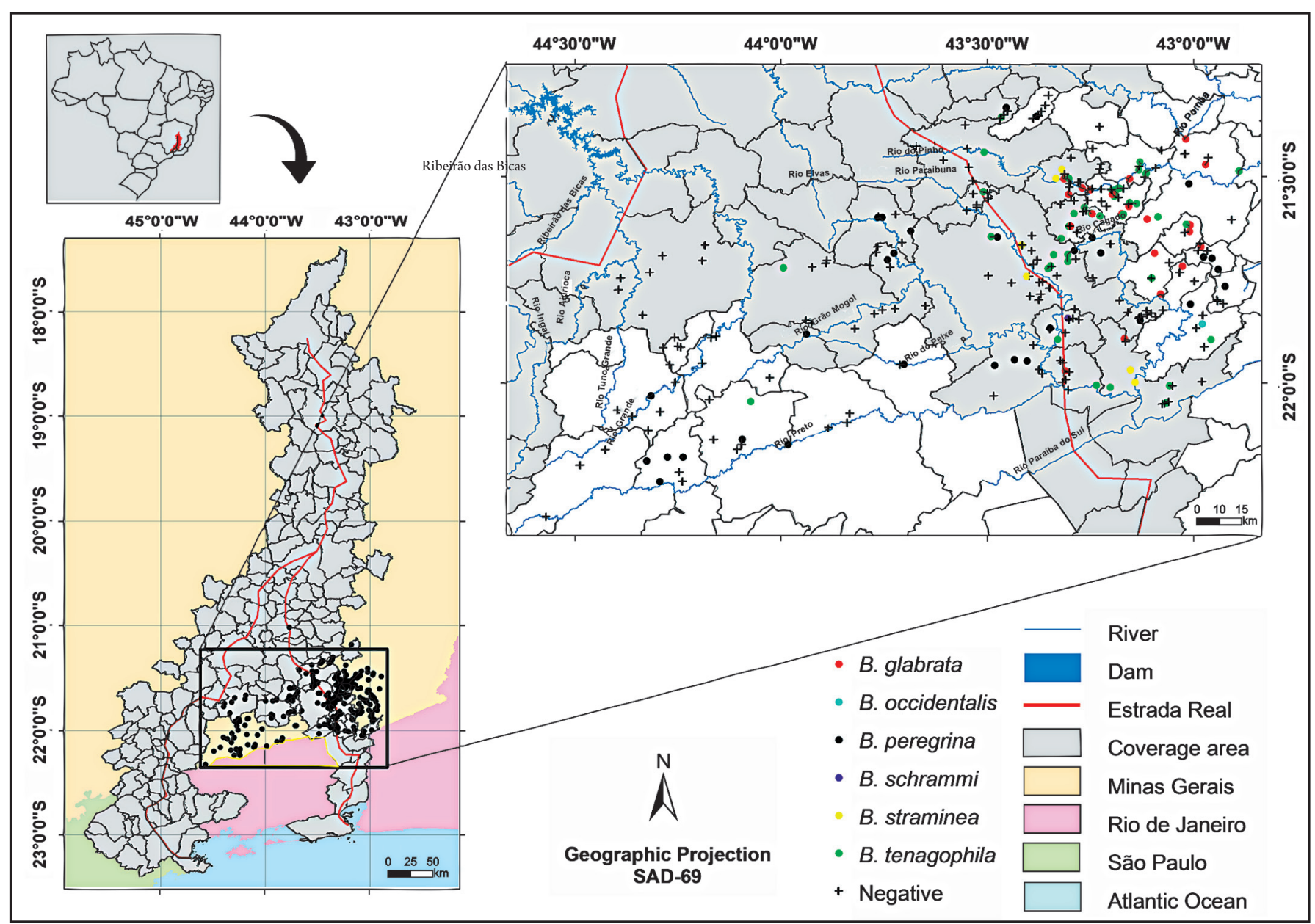

FIGURE 1 - Spatial distribution of the Biomphalaria genus in the municipalities of the Estrada Real, southeastern region of the State of Minas Gerais. The coverage area of the Estrada Real Project and highlighted, the Biomphalaria species collected in the municipalities of the Estrada Real in the southeast of the State of Minas Gerais. 
of the map, which is closer to the Caminho Velho (Diamantina/MG to Paraty/RJ). In the eastern region, between the rivers Pinho and Paraibuna, belonging to the Paraiba do Sul river basin, all the species of mollusks reported in this work were found. The western region, between the rivers Grande and Aiuruoca, belonging to the Rio Grande water basin, is the area with just one positive collection dot for $B$. peregrina. In the southern region, between the rivers Grande and Preto, belonging to the Rio Grande and to the Rio Paraiba do Sul water basins, respectively, there are various collection dots for B. peregrina, but only one positive dot for B. tenagophila (Figure 1).

\section{DISCUSSION}

Increased ecotourism and rural tourism in the State of Minas Gerais has highlighted the importance of studies regarding the occurrence of potential intermediate hosts of $S$. mansoni. This study revealed the presence of Biomphalaria snails in 30 municipalities, in the southeast region of the state, belonging to the Estrada Real Project or to its coverage area. This is a pioneering work, undertaken to investigate Biomphalaria snails in municipalities of the Estrada Real route with the use of geographic coordinates (GPS) for mollusk location.

In Brazil, there are 11 species and one subspecies of mollusks of the genus Biomphalaria, but only B. glabrata, B. tenagophila and $B$. straminea are recognized as intermediate hosts of $S$. mansoni. B. peregrina proved to be experimentally susceptible to $S$. mansoni, while B. occidentalis and B. schrammi proved to be refractory to infection ${ }^{22-26}$. B. tenagophila was present in $47.2 \%$ of the municipalities surveyed, B. glabrata in $33.3 \%$ and B. straminea in $8.3 \%$. Despite the undeniable importance of B. glabrata in Brazil, it is interesting to observe that $B$. tenagophila is the main species transmitting schistosomiasis in the State of São Paulo. These data reveal the importance of surveillance and the need for a control program for schistosomiasis in such areas, since B. glabrata showed significant occurrence and is of great importance due to its extensive geographic distribution, high infection indices and effectiveness in the transmission of schistosomiasis ${ }^{27}$.

Among the 36 municipalities studied, the absence of Biomphalaria snails was verified in only six. However, it is important to highlight that the present study was conducted over four years, which means that seasonal cycles, such as temperature and rainfall, for example, may have affected the abundance of mollusk populations ${ }^{28,29}$.

This study revealed several water collections colonized by mollusks of the Biomphalaria genus, including streams, dams and waterfalls, which could serve for sporting practices or for the construction of pools, providing further sources of infection by schistosomiasis among tourists $\mathrm{s}^{4,30}$.

The Estrada Real Project is based on the exploration of the touristic potential of the region, with the implementation of regional ecotourism and the preservation of the natural patrimony ${ }^{17}$. These goals also culminate, unintentionally, in maintaining the habitat of the intermediate hosts of S. mansoni, which may promote outbreaks and the spread of schistosomiasis in the region, since in the majority of these sites sanitation conditions are poor, representing contamination risks for water collections in cases of infected individuals.

Little information exists regarding the prevalence of schistosomiasis in the municipalities studied, because the region is generally considered to be of low endemicity ${ }^{18}$. The presence of Biomphalaria species was previously reported in the municipalities of Piau, Rio Novo and Juiz de Fora ${ }^{15,18,31}$, although considering their geographical location, only Juiz de Fora has been surveyed ${ }^{18}$. Models to estimate the prevalence of schistosomiasis have been perfomed in the State of Minas Gerais ${ }^{1,32-34}$ and in some Estrada Real municipalities ${ }^{16}$, but in both studies, due to lack of georeferenced information for Biomphalaria, only data concerning the prevalence of human schistosomiasis and Biomphalaria species in relation to the municipality were used. In this study, all the sites where the occurrence of Biomphalaria was verified were mapped using GPS. Knowing the exact location of the breeding/water collections of the intermediate host participant in the chain of transmission of schistosomiasis permits greater flexibility in structuring measures for disease control. Moreover, these data may favor the use of geostatistical techniques, generating predictive values for the occurrence of Biomphalaria at sites in the region with no information regarding the intermediate hosts $^{34,35}$, which could contribute to the drafting of a map of Biomphalaria snails in the State of Minas Gerais.

Considering the occurrence of schistosomiasis in the State of Minas Gerais and the socioeconomic repercussions that involve the Estrada Real Project, this work focuses on the vulnerability of the local water collections due to the presence of Biomphalaria mollusks and emphasizes the need for epidemiological surveillance and sanitary and education measures integrated with the local community and tourism sectors.

\section{ACKNOWLEDGMENTS}

The authors are grateful to the entire team of the Regional Healthcare Administration in Juiz de Fora, Minas Gerais, (GRS/ JF) and to Sandra C Drummond (State of Minas Gerais Health Administrative Office).

\section{CONFLICT OF INTEREST}

The authors declare that there is no conflict of interest.

\section{FINANCIAL SUPPORT}

This work was partially supported by FAPEMIG.

\section{REFERENCES}

1. Enk MJ, Amorim A, Schall VT. Acute schistosomiasis outbreak in the metropolitan area of Belo Horizonte, Minas Gerais: alert about the risk of unnoticed transmission increased by growing rural tourism. Mem Inst Oswaldo Cruz 2003; 98:745-750.

2. Barbosa CS, Domingues ALC, Abath F, Montenegro SML, Guida U, Carneiro J, et al. An outbreak of acute schistosomiasis at Porto de Galinhas beach, Pernambuco, Brazil. Cad Saude Publica 2001; 17:725-728.

3. Barbosa CS, Pieri OS, Silva CB, Barbosa FS. Ecoepidemiology of urban schistossomiasis in Itamaracá Island, Pernambuco, Brazil. Rev Saude Publica 2000; 34:337-341.

4. De Jesus AR, Silva A, Santana LB, Magalhães A, Jesus AA, Almeida RP, et al. Clinical and immunologic evaluation of 31 patients with acute schistosomiasis mansoni. J Infect Dis 2002; 185:98-105.

5. Gonçalves JF, Santana W, Barbosa CS, Coutinho A. Esquistossomose aguda, de caráter episódico, na Ilha de Itamaracá, Estado de Pernambuco. Cad Saude Publica 1991; 7:424-425.

6. Massara CL, Amaral GL, Caldeira RL, Drummond SC, Enk MJ, Carvalho OS. Esquistossomose em área de ecoturismo do estado de Minas Gerais, Brasil. Cad Saude Publica 2008; 24:13-22. 
7. Drummond SC, Pereira SR, Silva LC, Antunes CM, Lambertucci JR. Schistosomiasis control program in the State of Minas Gerais in Brazil. Mem Inst Oswaldo Cruz 2010; 105:519-523.

8. Lambertucci JR. Acute schistosomiasis mansoni: revisited and reconsidered. Mem Inst Oswaldo Cruz 2010; 105:422-435.

9. Lambertucci JR, Voieta I, Silveira IS. Cerebral schistosomiasis mansoni. Rev Soc Bras Med Trop 2008; 41:693-694.

10. Lambertucci JR, Otoni A, Reis MA. Nephrotic syndrome in hepatosplenic schistosomiasis mansoni. Rev Soc Bras Med Trop 2007; 40:492-493.

11. Drummond SC, Silva LC, Amaral RS, Sousa-Pereira SR, Antunes CM, Lambertucci JR. Morbidity of schistosomiasis mansoni in the State of Minas Gerais, Brazil. Mem Inst Oswaldo Cruz 2006; 101(suppl 1):37-44.

12. Teixeira R, Ferreira MD, Coelho PM, Filho GB, Azevedo Júnior GM, LambertucciJR Pyogenic liver abscesses and acute schistosomiasis mansoni: report on 3 cases and experimental study. Trans R Soc Trop Med Hyg 1996; 90:280-283.

13. Lambertucci JR, Rocha RS, Carvalho OS, Katz N. Schistosomiasis mansoni in Minas Gerais. Rev Soc Bras Med Trop 1987; 20:47-52.

14. Guimarães RJPS, Freitas CC, Dutra LV,Moura ACM, Amaral RS, Drummond SC, et al Schistosomiasis risk estimation in Minas Gerais State, Brazil, using environmental data and GIS techniques. Acta Trop 2008; 108:234-341.

15. Souza CP, Caldeira RL, Drummond SC, Melo AL, Guimarães CT, Soares DM, et al. Geographical distribution of Biomphalaria snails in the state of Minas Gerais, Brazil. Mem Inst Oswaldo Cruz 2001; 96:293-302.

16. Carvalho OS, Scholte RGC, Guimarães RJPS, Freitas CC, Drummond SC, Amaral RS, et al. The "Estrada Real" Project and endemic diseases: the case of schistosomiasis, geoprocessing and tourism. Mem Inst Oswaldo Cruz 2010; 105:532-536.

17. Federação das Indústria de Minas Gerais. Instituto Estrada Real - Conheça um pouco o "Instituto Estrada Real", sua atuação e seus objetivos [Internet]. [uptaded 2010 April 11; cited 2010 April 12]. Available from: http://www. estradareal.org.br/.

18. TibiricáSHC,BessaEC, MittherofheA, CastroMF, Carvalho ODOS, Caldeira R, et al. Biomphalaria spp. (Preston,1910) snails in the municipality of Juiz de Fora, Zona da Mata Mineira mesoregion, State of Minas Gerais, Brazil. Mem Inst Oswaldo Cruz 2006; 101:179-184.

19. Paraense WL. Estudo atual da sistemática dos planorbídeos brasileiros. Arq Mus Nac 1975; 55:105-128.

20. Paraense WL. Biomphalaria occidentalis sp. from South America (Mollusca: Basommatophora: Pulmonata). Mem Inst Oswaldo Cruz 1981; 76:199-211.

21. Vidigal THDA, Caldeira RL, Simpson AJ, Carvalho OS. Further studies on the molecular systematic of Biomphalaria snails from Brazil. Mem Inst Oswaldo Cruz 2000; 95:57-66

22. Coimbra Jr CEA, Engel LA. Suscetibilidade de Biomphalaria occidentalis do Acre e Mato Grosso à infeção pelo Schistosoma mansoni e sua implicação na epidemiologia da esquistossomose na Amazônia Ocidental, Brasil. Acta Amazonica 1982; 12:795-799.

23. Corrêa LR, Paraense WL. Susceptibility of Biomphalaria amazonica to infection with two strains of Schistosoma mansoni. Rev Inst Med Trop São Paulo $1971 ; 13: 387-390$.

24. Paraense WL, Corrêa LR. Susceptibility of Biomphalaria peregrina from Brazil and Ecuador to two strains of Schistosoma mansoni. Rev Inst Med Trop São Paulo $1973 ; 15: 127-130$.

25. Paraense WL, Correa LR. Insusceptibility of Biomphalaria occidentalis to infection with a strain of Schistosoma mansoni. Mem Inst Oswaldo Cruz 1982; 77:55-58.

26. Souza CP, Passos LKJ. Resistance of Biomphalaria occidentalis from Varzea das Flores Dam, Minas Gerais, to Schistosoma mansoni infection detected by low stringency Polymerase Chain Reaction. Mem Inst Oswaldo Cruz 2001; 96:381-383.

27. Caldeira RL, Jannotti-Passos LK, Carvalho OS. Molecular epidemiology of Brazilian Biomphalaria: a review of the identification of species and the detection of infected snails. Acta Trop 2009; 111:1-6.

28. Freita JM. Ecologia de vetores de doenças. O habitat da Biomphalaria glabrata. Cien Cult 1976; 28:212-217

29. Grisolia MLM, Freitas JR. Características físicas e químicas do habitat da Biomphalaria tenagophila (Mollusca, Planorbidae). Mem Inst Oswaldo Cruz $1985 ; 80: 237-244$
30. Enk MJ, Caldeira RL, Carvalho OS, Schall VT. Rural tourism as risk factor for the transmission of schistosomiasis in Minas Gerais, Brazil. Mem Inst Oswaldo Cruz 2004; 99:105-108.

31. Freitas CA. Situação atual da esquistossomose no Brasil. Rev Bras Malariol D Trop 1972; 24:31-55.

32. Paraense WL, Deslandes N. Observations on Australorbis janeirensis (Clessin, 1884). Rev Bras Biol 1956; 16:81-102

33. Guimarães RJPS, Freitas CC, Dutra LV, Moura ACM, Amaral RS, Drummond SC, et al. Analyses and estimative of schistosomiasis prevalence for Minas Gerais State, Brazil, using multiple regression with social and environmental spatial data. Mem Inst Oswaldo Cruz 2006; 101:91-96.

34. Guimarães RJPS, Freitas CC, Dutra LV, Scholte RGC, Martins FT, Fonseca FR, et al. A geoprocessing approach for schistosomiasis studying and controlling in the State of Minas Gerais - Brazil. Mem Inst Oswaldo Cruz 2010; 105:524-531.

35. Guimarães RJPS, Freitas CC, Dutra LV, Felgueiras CA, Moura ACM, Amaral RS, et al. Spatial distribution of Biomphalaria mollusks at São Francisco River Basin, Minas Gerais, Brazil, using geostatistical procedures. Acta Trop 2009; 109 . 181-186. 